\title{
Recursos da História Oral em Narrativas Sobre o Hiv/Aids
}

\author{
Alves, Milene; Paes, Pedro Pinheiro; Almeida Jr., Wilson N. \\ Universidade Federal de São Paulo/Unifesp — milene.alves@ymail.com
}

INTRODUÇÃO: Histórias de pessoas que vivem com HIV/aids, emergem segredos e individualidades. para ecoar esses significados, o pesquisador pode se apoiar nos recursos da história oral $(\mathrm{HO})$. Essa abordagem dispõe de procedimentos diferenciados, e estão além da transposição do oral para o escrito. Meihy \& Holanda (2010, p. 157-158) sustentam a tese da transcriação, onde o texto construído a partir desta metodologia, apresentará as singularidades da fala. Conferindo uma forma diferente, a HO é apropriada para tratar temas de relevância social e as subjetividades inerentes às experiências de vida, garantindo o anonimato e uma narrativa de alcance público. OBJETIVOS: Compreender a partir das narrativas de pessoas que vivem com HIV/aids, como acontece a adaptação e o ajustamento social diante das adversidades da doença. METODOLOGIA: Historia oral de vida aplicada a saúde, através da entrevista colaborativa, que é estruturada com fundamentos elementares: explicitação do tema, objetivo do projeto, poucas perguntas de corte, sem roteiro pré determinado. As falas são gravadas, transcritas, transcriadas, posteriormente devolvida aos entrevistados/ colaboradores como texto. Colaboram com esse trabalho 2 homens, com idades entre 38 e 56 anos, que concordaram em assinar uma carta de cessão. RESULTADOS: Temas emergiram das falas, num primeiro plano perpassam pela resiliência e ressignificam os sentidos (FRANKL, 2008) foi a escolha pela vida: ..."o corpo é meu, é nele que habito". a adesão ao tratamento medicamentoso: ... "o vírus é um intruso". Importância de espaços para praticar de atividade física sem sofrer preconceitos; mobilização e ativismo. a resiliência como conceito tem sido discutida nas últimas décadas do século $X X$, especialmente na área da saúde, caracteriza 0 enfrentamento de situações que a priori podem ser compreendidas como aniquiladoras, mas que servirão de principal fator na mudança de atitude frente à própria vida (ARAUJO, 2011). CONCLUSÕES: As narrativas orais oferecem muitas leituras e abordagens, recuperam particularidades dos envolvidos, desvelando a memória coletiva. ao narrar sua história o colaborador, narra as histórias de outros, isso é parte do contexto histórico e não pode ser deixado de fora. o efeito dessas falas transformam aquele que narra e também aquele que escuta. REFERENCIAS BIBLIOGRÁFICAS ARAUJO, C.A. MELLO, M. Ap. RIOS, A.M.G.(2011) Resiliência: Teoria e práticas de pesquisa em psicologia. Ithaka Book: São Paulo, 222 p. Frankl, V.E (1991). Psicoterapia e sentido da vida. Campinas: Papirus. Meihy, J. C. B. \& Holanda, F. (2010). História Oral: como fazer, como pensar. (2a․ ed) São Paulo: Contexto.

Alves, Milene; Paes, Pedro Pinheiro; Almeida Jr., Wilson N.. Recursos da História Oral em Narrativas Sobre o Hiv/Aids. In: Anais do Congresso Internacional de Humanidades \& Humanização em Saúde [= Blucher Medical Proceedings, num.2, vol.1]. São Paulo: Editora Blucher, 2014. ISSN 2357-7282 DOI 10.5151/medpro-cihhs-10755 